\title{
'Big Think', Disjointed Incrementalism: Chinese Economic Success and Policy Lessons for Africa, or the Case for Pan-Africanism
}

Jean-Germain Gros*

\begin{abstract}
Chinese economic success is not the product of free market accidental coincidence. Rather, it is orchestrated by the State through a mixture of nationalism ('big think') and pragmatic decisions (disjointed incrementalism) in agriculture, finance and industry. Furthermore, these decisions build upon existing institutions (e.g. the Household Responsibility System, Township Village Enterprises, etc), some dating back to pre-revolutionary China (e.g. Special Economic Zones), rather than imported ones from outside China. The article explores the utility (and lack thereof) of the Chinese model in the African context, as well as the possibilities of an Africa-centred 'big think' (Pan-Africanism) capable of mobilizing the continent for development.
\end{abstract}

\section{Résumé}

L'essor de l'économie chinoise n'est pas le produit des miracles du marché libre. Au contraire, il est l'oeuvre de l'Etat chinois à travers un mélange heureux de nationalisme et d'une politique décisionnelle pragmatique portant sur l'agriculture, les finances et l'industrie. En outre, cette politique pragmatique est basée sur les institutions chinoises, comme, par exemple, le Système de Responsibilité des Ménages, les Entreprises Villes-Villages et les

\footnotetext{
* Department of Political Science, University of Missouri-Saint Louis, USA. Email: jg.gros@umsl.edu
} 
Zones de Libre-Echange, au lieu d'être basée sur les institutions importées. Cet article met en examen l'utilité du « modèle » chinois au contexte africain, et explore les possibilités d'un nationalisme africain axé sur le Pan-Africanisme comme moyen de mobiliser le continent pour le développement.

\section{Introduction}

When economic historians write the development record of the last decades of the twentieth century, they should have good cause for casting China as the success story of that fin de siecle. From 1979 to 1997 China's annual GDP grew by an average of 10 percent, an accomplishment matched (and surpassed) only by the former Soviet Union in the 1920s and 1930s. Chinese industrial production in the late 1990s was seven times larger than in 1978, and total trade fourteen times larger. Economic growth in China has resulted in improved living standards: real income per capita more than quadrupled between 1979 and 1997, thereby lifting more than 200 million out of absolute poverty (World Bank 1997). Chinese steel production increased by 50 percent between 2000 and 2004 , evidence of a buoyant industrial sector ready to churn out durable goods for the largest middle class in one country in history and for the world economy (Avery 2005).

Historians are less likely to be excited about Africa's economic performance during the same period, and indeed since decolonization in the 1960s. By every imaginable index of socio economic performance, Africa has been moving backward rather than forward. The statistics are telling, if not to say depressing: Sub-Saharan Africa accounts for just 1 percent of world industrial production, down from 4 percent in the 1960s. It experienced virtually no economic growth in the last two decades of the twentieth century, in spite of Structural Adjustments Programs (SAPS), which were supposed to set Africa on a path of sustainable development. Africa is home to more than half of the world's poorest countries. Naturally, the polarity in economic achievement between China, the world's fastest growing economy in recent years, and Africa, its poorest continent, invites scrutiny, as well it should. This article makes three points.

Firstly, Chinese economic success owes much to the state, which, through a mixture of nationalism ('big think') and pragmatic decisions (disjointed incrementalism) in specific policy areas, such as agriculture, finance, trade and industry, has catapulted China to economic super- 
power status in less than 3 decades. It has done so not by absolute command and control of productive assets, but by centralizing macro-economic and social policy making while devolving policy implementation to regional and local officials of the Chinese Community Party, which of course remains an organ of the national state. This allows centralized authority to maintain control over the Chinese hinterland; the state can bring to heel local officials who bring disrepute to Communist Party rule, even while these same officials have been given wide latitude to bring development to their area without diktat from Beijing. Thus, China shows that centralization and decentralization are not mutually exclusive, but can be apportioned according to policy area.

Secondly, the success of China's developmental state ${ }^{1}$ is based on innovations made on existing institutions - some predating the Chinese Revolution - rather than the creation of new institutions. Chinese leaders have proven to be particularly adroit at adapting social institutions to their vision of reform. The Household Responsibility System (HRS) and the Township and Village Enterprises (TVEs) are two examples of institutional innovations, which have largely resolved agency and soft budget constraint problems without privatization. China's Special Economic Zones (SEZs) show how capital-starved countries can attract capital through direct foreign investment (DFI), as well as how the latter can contribute to the development of host economies. These SEZs were established in areas (southern coastal China), which had served as China's window to the world economy in the second half of the nineteenth century. Shut to capitalists during the Mao Zedong era, these former trading outposts were reopened after 1979 and would become the industrial engines of China's economy with capital pouring in at first from overseas Chinese and later foreign investors.

Thirdly, certain aspects of the Chinese reform experience are of import to Africa. For example, China's centralization of development policy making and decentralization of implementation is extremely insightful for Africa, where one of the unfinished debates is the contention between nationalists, who favour a decentralized approach to economic development, and Pan-Africanists, who advocate a regional approach leading ultimately to continental economic development. China shows that, under the right circumstances, the dichotomy may be largely spurious. ${ }^{2}$ Equally, an overarching ideology of 'big think' articulated by a strong state committed to development but willing to engage in policy experi- 
mentation using sub-national officials and existing social institutions are not incompatible. China further demonstrates that it is possible to improve economic performance by substituting the incentives typically associated with markets with others so as to affect the behaviour of producers, consumers and investors (Taylor 2005).

The 'shock therapy' of neo-liberalism imposed by the West and its institutions (the World Bank) in the 1980s and 1990s, with its panoply of pro-market reforms (e.g. privatization, currency devaluation, trade liberalization, government retrenchment, etc.) is not the only option for Africa, and is quite possibly the wrong option. China, which has yet to make firm guarantees to private property rights, defies contemporary economic orthodoxy and may be all the better for it. Africa, which may have applied neo-liberalism's Structural Adjustment Programs (SAPs) more rigorously than any other continent with little to show, can learn from China's nuanced approach to development, which uses state and market, or, to use the idiom of administration, centralization and decentralization.

The article does not glorify China, whose development has not been without costs. Chinese economic success has been regionally and socially uneven, politically undemocratic and demographically inhumane. Thus China's one-child policy would never pass cultural muster in Africa (which is not to say that population growth should not be controlled; the question is how). It is true that, historically, economic transformation has never been achieved without severe human costs, but the latter must never be accepted as the inevitable price of progress. Economic development in Africa will have to grapple with the issue of equity; that is to say, instead of making some people rich first in the hope that their wealth will eventually trickle down to others, Africa will have to insure that the fruits of development are savoured by everyone, perhaps not equally but certainly equitably. For a country that still calls itself socialist, China tolerates a degree of socio-economic inequality that Africans should find unacceptable.

In addition, China is facing an ecological crisis because of the pollution wrought by rapid and poorly regulated industrialization. Water pollution alone is estimated to cost between 3.5 and 8 percent of GDP (World Bank 2007). Given the fragility of Africa's ecosystem, with one third of its landmass already claimed by the Sahara desert, the continent can ill afford additional ecological degradation as the price to pay for industrialization. Whatever economic development occurs in Africa in 
the future has got to be environment-friendly; the natural abode is already too degraded in much of the continent to permit additional ravages by industry. In sum, the article recognizes the limits of China's development, and whatever positive lessons provided by the Chinese experience will have to be adjusted to the African condition (hence the call at the end for Pan-Africanism).

The article is organized as follows. The next section recognizes the methodological challenges of comparing China and Africa, while making what the writer thinks is a strong case for this type of research. The two sections after that discuss disjointed incrementalism and 'big think' in the Chinese context. As a policy instrument, disjointed incrementalism builds upon existing institutions rather than create new ones; it also dissipates some development decisions to subalterns, thereby facilitating policy experimentation. Alongside our focus on the application of disjointed incrementalism in China, we look in Africa for institutions upon which a similar approach to development policy might be built. The last section of the article is an examination of what an African version of 'big think' might look like, in the light of African reality.

\section{Methodological Challenges}

Any comparative analysis always runs the danger of examining phenomena that are so fundamentally different as to make the enterprise a risky endeavour. Where comparison between China and Africa is concerned, this study recognizes these limiting factors.

Firstly, and most obviously, China is a nation-state while Africa is a continent. This difference is very significant, inasmuch as one government makes authoritative decisions in China, while in Africa 50 do so. Hence, whatever the secrets to Chinese economic success, they may not be so easily unravelled by African governments of differing administrative capacities, ideologies and leaderships. Africa's political atomization also makes for more restricted movement of goods and people across space, as well as systemic differences in such important determinants of economic performance as natural resource endowment, law, money, security, human capital, etc.

Secondly, China and Africa do not have the same geography: one is on the western end of the East-West axis while much of the other pivots along the North-South axis. Differences in geographic location have development consequences, not least in terms of the receptivity of econo- 
mies to technological innovation developed elsewhere, the compatibility of eco-systems (which facilitates the transplantation of new crops and animal species) and ease of travel (Diamond 1997). Geography may not be destiny but it is not a negligible quantity in economic history, or, for that matter, history tout court. It was kind to China, most unkind to Africa, in the late twentieth century. Specifically, China was fortunate to be surrendered by success stories from which it could learn and which were also major investors in its economy (e.g. Japan and Taiwan). African countries, by contrast, are beset by poverty in their neighbourhood.

Thirdly, it is possible that China's success may be due to factors that are unique to China, in which case it would be extremely difficult for any aspiring developer to use the Chinese model to its advantage. In some ways China has been the beneficiary of the self-fulfilling prophecy of high achievement, which works approximately as follows. The world expects China to be a great power and the largest market in one country in history. Consequently, foreign investors flock to China in the hope of establishing a presence before it is too late; they are even willing to incur short-term financial losses and put up with institutional shortcomings, often in return for little more than expectation of fabulous profit taking. In part, because of this (irrational?) exuberance, China becomes the success everyone predicted it would be, because it is the recipient of much needed direct foreign investment (DFI). No such expectation, of course, pertains to Africa, which lacks China's demographic clout (e.g. 22 percent of the world's population); as a result, investors stay away, the continent is starved for capital, and its development remains mired in the rut.

Notwithstanding the aforementioned limitations, there are strong arguments in support of the kind of comparative analysis undertaken in this article. China and Africa are (still) in the same geo-political and economic imaginary known as the Third World, whose existence as a theoretical construct scholars continue to accept, in spite of the fact that it is not a monolith. Officially, China's per capita Gross National Income or GNI ( $\$ 2,010$ in 2006 dollars) is much closer to (sub-Saharan) Africa's per capita GNI $(\$ 1,418)$ than it is to that of the developed world, as represented in the OEDC countries $(\$ 40,248)$ (International Finance Corporation n.d.). Thus, we are not talking about entities that are, in aggregate macroeconomic terms, in vastly different universes, which would therefore preclude useful comparison. 
Further, it has long been a tenet in the social sciences that economic development, for good and ill, has 'demonstration effects'. Most of the great academic debates since World War II, from modernization theory to dependency theory, from neo-liberalism to post-modernism, have been underwritten by the exportability and desirability of this or that economic model. World policy makers have also erred in a similar direction by their actions. Indeed, the architecture of international relations since 1948, with its multilateral institutions strewn across the globe, reflects a profound belief in the transmutation of economic development and, on a less flattering note, a hubris in western capacity to bring it to the 'rest'. The Cold War was in part about how many countries in the periphery or Third World would adopt economic systems and ideologies developed in more advanced countries.

In brief, the kind of metastasized analysis expounded in this article is not the first, although this type of research is increasingly (and unfortunately) rare (for reasons discussed later). Metaphorically speaking, the aim of this paper is to find out the proverbial Chinese menu entrées that may have their equivalents in the African gastronomy. More concretely, it is not suggested that Africa should adopt - lock, stock and barrel - the Chinese 'model,' but this paper is interested in extracting from the Chinese experience broad lessons and principles, which, when adapted to the African milieu, may yield similar results. It is equally interested in investigating the pitfalls of economic development in China so they may be avoided in Africa, as well as examining where Africa may have gone wrong while China has not.

Finally, and perhaps more importantly, there has been a profound gap in the social studies since at least the 1960s, when so-called experts invaded the academic scene. The net result has been not only the artificial separation of disciplines that should be natural allies (e.g. economics and political science; sociology and anthropology; geography and area studies, etc.), but their sequestration to enemy camps that increasingly engage in intestinal fights over dwindling resources, prestige and turf protection. In this environment of hyper-specialization, where a simulacrum of seemingly value-free data is conflated with true scientific objectivity, newly minted $\mathrm{PhDs}$ know a great deal about the limited areas in which they are trained, including the methods and mathematical models which they are told are so indispensable to 'scientific' work, and precious little about everything else. Worse, their training has desensitized them to thinking outside of the box. This is a real disservice in a 
world where distance is literally being shrunk by communications and transportation technologies, not to mention the oft-stated phenomenon of globalization. In this world, China cannot be ignored. Its weight in the geo-political balance and rapid ascendance in the global economy militates against such an exclusion. Nor can Africa, arguably the world's richest continent in terms of natural resources and, perhaps because of this, the key to future prosperity, be sidelined. There are, therefore, strong reasons to study China and Africa in tandem rather than isolation.

This article brings together these two seemingly inchoate areas of the world economy, which, judging by their recent performance and growing ties, are as polar opposites as they are complementary. It has the further merit of attempting to bridge the gap between two spheres of inquiry (Sinotology and African Studies) that the intellectual ghettoization spoken of earlier has tended to widen. It is a 'thought' piece meant to resuscitate what has become a lost art - i.e. the examination of big ideas and challenges, using large units of analysis - as well as provoke debate among Africanists and Chinese specialists.

The author had the privilege of starting academic life as an Africanist, but serendipitously 'stumbled' upon China in the early 2000s, coincidentally the period during which China's economic engagement in Africa appears to have intensified, as its own economy went into overdrive. The net result has been the fusion of interest in these two areas and the production of a series of articles (published in both places), of which this one is the latest instalment. The method employed in this article is that of the participant-observer; the data are overwhelmingly secondary, with 'primary data' consisting of structured interviews and informal conversation with Chinese colleagues at the headquarters of the Chinese Academy of Social Sciences (CASS), the Institute of West Asian and African Studies and the Ministry of Foreign Affairs - all in Beijing.

\section{The Chinese Way}

China's approach to economic development is based neither on laissez faire nor command principles. The first suggests a political economy in which market forces totally dictate resource allocation, with government relegated to providing basic public goods including security. The second connotes the obliteration of markets and their total replacement by the state, which owns all productive assets and makes production decisions based (ostensibly) on social needs rather than profit making. 
Chinese attempt at economic development since 1979 belies the aforementioned extremes. Many of China's reforms run counter to the tenets of neo-liberalism. At the same time, China has clearly moved away from a command economy, which historically has had these characteristics: central planning, collectivized agriculture, state control of industrial assets, an egalitarian ethos, etc. Chinese economic policy is largely non-socialist, even though Chinese officials in the Deng era occasionally give a wink and a nod to socialism (always with the qualifier: 'with Chinese characteristics' under Deng). It is very revealing that President $\mathrm{Hu}$ Jintao's imprint on Chinese ideology is called 'scientific development', as opposed to 'socialist development' or 'scientific socialism', as would have been the case under Mao Zedong. The current leadership in China has virtually expunged the word socialism from everyday discourse, and, more importantly, policy.

Instead, China has followed in the footsteps of other Asian developmental states, such as Japan and South Korea. In these countries, as well as Malaysia and Singapore, states 'intervene actively in the economy in order to guide or promote particular substantive goals e.g. full employment, export competitiveness, energy self-sufficiency' (Chan 1990) but do not own the means of production outright. There is more state ownership in China, because of its history of a command economy, but it is moving toward a mixed system, in which the state's role is akin to that of an orchestra conductor rather than one of its players. The so-called China way would seem to confirm the 'demonstration effects' thesis.

Chinese economic reforms have proceeded in broad stages, reflecting the inherent caution of incremental policy making, as well as the reality of sharp differences inside the Chinese Communist Party (CCP) between liberals (i.e., those who favoured market reforms) and conservatives (i.e., those who favoured state control through central planning). Thus the Chinese approach to economic development has not followed a straight, linear and unimpeded course. Rather, the path has been littered with obstructions, which the Chinese leadership has managed to overcome but not without making tactical concessions along the way. Chinese economic policy making has been described as 'crossing the river by feeling for stones', meaning making adjustments to policy as circumstances warrant. A preferable description would be disjointed incrementalism. 
Disjointed incrementalism is a complex form of strategic analysis, which is based on Herbert Simon's concept of bounded rationality. It entails focusing on policy choices that differ incrementally from existing policies; using a relatively small number of policy alternatives (usually not more than three or four); evaluating policies on the basis of 'important' consequences, rather than the entire universe of possible consequences; countless end-means and means-end adjustments through trials and errors; and finding solutions that are 'good enough' to ameliorate current problems (Etzioni 1967). Karl Popper (1961) had perhaps the best definition of disjointed incrementalism, which he termed piecemeal social engineering. 'The piecemeal engineer will avoid undertaking reforms of a complexity and scope which make it impossible for him to disentangle causes and effects, and to know what he is really doing' (Popper 2002).

As a decision making type, incrementalism has been accused of conservatism, and, according to critics, there are circumstances in which bold actions, or synoptic decisions, are necessary. In addition, even incremental decisions need theory (Gordon and Waldner 1979). Incrementalism need be neither conservative in outcome nor indifferent to theory, or a larger picture. Modest steps, if taken often enough, can have important cumulative effects ushering in significant change. Furthermore, modest steps can take place against the larger backdrop of a foot race, hence the proverb about the 1,000-mile journey, or de la Fontaine's fable of the tortoise and the hare. On the other hand, major decisions made infrequently and erratically may give the illusion of change while maintaining the status quo. They can also be made by decision makers, who eschew theory and act purely on whims.

China's disjointed incrementalism has taken place in the larger context of 'theory' or 'big think', thus disputing critiques of the incremental model. Generically, 'big think' refers to attempts by a political community to rally its members around goals and objectives, whose achievement will ostensibly lead to collective welfare (typically defined in terms of security, stability and prosperity, or the goals of statecraft). In the modern age, where political communities are organized into nation-states, 'big think' is a euphemism for nationalism, the expression of which is conditioned by a variety of factors, including the history of the political community (e.g. how it experienced colonialism), the ideology of state elites and how they came to power (through violent revolution or some 
type of negotiated transition) and the extent of the political community's integration into the international system.

In the case of China, 'big think' implies a conception of the country as a great power, probably from the very beginning. Thus, in ancient times China was the Central Kingdom (Zhon Guo), which presumably entails a political community whose pre-eminence surpassed all others. ${ }^{3}$ In the 19th century, even when parts of China were conquered by imperialist powers and centralized authority in Beijing was extremely weak, this ethos persisted. In the early 1960s, disagreement between China and the former Soviet Union had more to do with Chinese nationalism than communist ideological differences. In the latest incarnation of Chinese 'big think', the state has ensconced development in improving economic performance, in order to maintain autonomy at home (self-reliance), project power and influence abroad, legitimize Chinese Communist Party (CCP) rule and oversee China's 'peaceful rise' (to superpower status).

In sum, 'big think' in contemporary China is an ideology conceived by the state to sell the legitimacy of its control by the Chinese Communist Party, based on the latter's management of the economy, its ability to defend China against the historical humiliation of foreign occupations and the (re) unification of the Chinese mainland with prodigal territories such as Taiwan. Chinese 'big think' interprets the past, justifies the present and promises an even better future, but only if China remains united and under the leadership of the CCP. Simply put, 'big think' is 'classic' nationalism with a strong component of economic development as a means of preserving the social and territorial integrity of the Chinese community through the state.

The 'uniqueness' of China, even in comparison to Asian developers such as Japan and South Korea, is that in the past nationalism was often used as a justification for centralizing state power and pursuing economic development based on dirigiste principles. Chinese nationalism has accommodated administrative decentralization without political liberalization in the pursuit of a mixed economy. It has devolved considerable power to sub-national officials in a unitary, one-party state, who have infused competition in the economy but not in governing. What has made this coexistence possible is the legitimacy of the institutions of decentralization, which are examined next, respectively in agriculture, industry, finance and foreign investment. 


\section{Disjointed Incrementalism in Action}

\section{Agriculture}

China has pursued land reform based on the so-called household responsibility system, which is tantamount to the state granting de facto private property rights through a long term lease of land while it retains de jure ownership. The lessee obtains user rights, which can be used to secure income, transfer or sell the leased land, although in the latter two cases transactions take the form of subletting. The state exacts various kinds of dues on lessees, which in effect become fixed property taxes (Chan 1990). The household responsibility system (henceforth HRS) infuses private incentives in Chinese agriculture, even while the state maintains property rights over land, which, in theory, gives it significant power in the rural economy. It can allocate land use rights based on criteria set by the Chinese government, raise land rent and taxes and even alienate land from agriculture and channel it toward other purposes (the Three Gorges Dam is a case in point).

The HRS has been introduced in China at least four times since the revolution. On every occasion, it was implemented on a limited basis, where it was tested before being expanded (again, further evidence of disjointed incrementalism). China allowed the so-called two-land system in Pingdu province, where plots were divided between those devoted to growing food for household consumption (kouliang tian) and those reserved for commercial farming (chenbiao tian). In the first equity was the driving principle for distribution, in the second efficiency was the overriding value. Farmers who had the inclination and ability were allocated larger parcels for commercial farming (which meant contract farming with the government). In Shunyi, collective farms (re)emerged in the 1980s. They were facilitated by their location in areas of high rural industrialization, as well near major cities with sound infrastructure where mass-produced agricultural commodities could be taken quickly to market. In Nanhai, farmers became land 'shareholders'. They could turn land use rights into land shares. In this way, individual plots could be amalgamated into bigger ones cultivated by farming teams. Individual farmers, now 'shareholders', received their benefits in the form of dividends. In this way, too, farmers did not have to give up their land use rights when they sought employment outside of the farming sector. 
In other words, land reform in China was sensitive to local specificity, which gave the policy legitimacy and locals a stake in its success. China did not have a one-size-fits-all approach to agricultural reform, which might have been resisted, such as privatization or its antidote (collectivization), although the guiding philosophy embedded in the HRS was the same: providing farmers with the incentives to produce more, maintaining at least nominal state control over land, and creating synergy between agricultural production and industrialization (through the Township and Village Enterprise, discussed below).

More recently, China has invested massively in the agricultural sector. Agricultural lending more than doubled between 2000 and 2005, rising from 60 billion to 145 billion USD. In mid-2005 this represented 6.5 percent of all loans (Gale and Collender 2006). Given China's need for capital elsewhere, e.g. manufacturing, housing, energy and infrastructure, this substantial injection of capital in agriculture may seem surprising. But 'Chinese policymakers hold the view... that rural poverty can be solved by an infusion of cheap credit and they are attempting to reverse the historic outflow of funds from rural savers to urban borrowers' (ibid). In addition to boosting rural income, agricultural lending is aimed at increasing grain production, a priority of Chinese policymakers, who fear that importing large quantities of grain could negatively affect China's balance of trade and undermine the country's effort to achieve food self-sufficiency. The state's entrance in the agricultural sector as a provider of credit but not as a direct and active landowner underscores, once again, the fusion of centralization and decentralization, the marriage between 'big think' (exemplified in this case in the desire to make China self-sufficient in staple food) and disjointed incrementalism (the idea that farmers in China should ultimately be able to enjoy the fruit of their labour, and that farming activities should be based on local conditions).

What does China's approach to agriculture portend for Africa? Rural China and Africa are, in at least one important respect, similar. When one buys land in Ghana, for example, one enters, technically speaking, into a long-term leasing agreement with a traditional chief, who holds the land in trust on behalf of 'his' subjects and who should share the proceeds of the lease with them. Except for southern Africa, whose agriculture underwent significant capitalist transformation in the late nineteenth century, land is communally owned in much of Africa as it was (is) in China, with traditional authorities serving as fiduciaries. This 
pattern of ownership does not necessarily create a 'tragedy of the commons', or severely impede economic performance. Famine does not seem to have been a frequent occurrence in pre-colonial Africa, although this may have been due to population growth rates that either remained stagnant or declined (in some cases, clearly because of the transatlantic slave trade). It did become a major problem during colonialism, when land was appropriated on a massive scale to create the large industrial farms (palm oil in Cameroon and Nigeria, rubber in Liberia and, especially, cotton in Lusophone Africa).

While land was (is) held by traditional authority on behalf of their subjects, the latter were (are) encouraged to practice self-reliance either individually, or more often, collectively through the extended family. The ubiquity of land use rights, as opposed to private property rights, in much of Africa must be seen as a compromise between the communitarian ideal of land as a sacred trust to which members of the community must have access and the more individualistic ideal of responsibility and selfreliance, which particularly in pastoral cultures were deemed necessary for males to marry. Traditional Africa had a wonderful capacity to craft hybrid institutions that rewarded individual talent and efforts and maintained communal interest and control.

For example, among the Peuls of northern Cameroon, a young man had to have so many head of cattle before his parents would agree to approach the family of the potential bride for a marriage proposal, this while much of the grazing land was communally owned. To be sure, marital status and biological reproduction were tied to personal achievement for males, but the individual remained firmly ensconced in the community through the institution of the arranged marriage and common ownership of pasture. Simply put, a potential groom could display industry through herd size, as this was a precondition for marriage, but was not expected to go off entirely on his own to accumulate wealth and (or) wives.

Even today and even in urban Africa, it is a rare African in whose success the community (meaning here mostly the extended family) did not participate and, consequently, is not expected to share. Any reform of agriculture in Africa, if it is to succeed, cannot run roughshod over this delicate balance between individualism and 'communitarianism'. The problem with land in much of Africa today (e.g. Ghana) is the fuzzy line among different forms of ownership - state, community and individual land - and the inconsistent enforcement of ownership rights (whatever 
they may be), which raises the price of land via higher transaction costs. The solution to this brigandage is not privatization but more transparency in land ownership rights and greater willingness on the part of the state to enforce the rules.

China shows that it is possible to improve agricultural performance without overturning traditional land ownership patterns. It is always puzzling to hear the same analysts who correctly point to institutional mismatch as one of the sources of failure of collectivized agriculture in the former Second World, yet in the same breath uncritically embrace private property rights as the universal solution to improving agricultural performance in the Third World. Incentives are not a monopoly of the capitalist mode of production. Increasing farm output does not necessarily mean privatizing farmland. Private ownership of land is but one incentive to agricultural performance among many, and its ubiquity in the so-called West is a product of a particular historical experience, which cannot be assumed to have universal currency. China, once again, has yet to make firm guarantees to Western-style private property rights, but this ambiguity has not suffered economic performance. Other stimulants of agricultural performance include: liberalization of restrictions on farming surplus value, farmer access to credit and (or) intrants (e.g. fertilizers and improved seeds) and farmer ability to transport goods to market.

Along with the HRS the state encouraged the development of Township and Village Enterprises (TVEs), which were intended to break the historical dichotomy between agriculture and industry, by fostering the integration of these activities. This is reflected in the quintessentially Chinese dictum: leaving the land but not the countryside, entering the factory but not the city. TVEs were not invented by Chinese reformers; they were adaptations to the commune and brigade enterprises created during the Great Leap Forward, which were originally intended to absorb surplus labour in the rural areas. After 1978, agricultural reform in China led to such a sharp rise in rural incomes that the output of the TVE could be readily absorbed, thus creating a viable rural market for both goods and labour and, just as importantly, synergy between agriculture and industry. TVEs share these features: 'they are publicly owned but market oriented; they are small in size, enjoy a high degree of autonomy of operations; they are much more outward-oriented than stateowned enterprises (SOEs); they are subject to hard budget constraints' (Fu and Balasubramanyam 2002). 
The last feature of the TVEs comes from the fact that such organizations receive very little support from the state-owned banks and can go bankrupt if they are chronically unprofitable. This feature also solves the principal-agent problem, inasmuch as TVE managers (agents) are under pressure to perform, that is to say, to act as de facto owners cum local governments (principals) would have acted if they had the managers' alleged expertise. The agents cannot remain passive to firm performance, since their salaries and bonuses depend on profitability, and the principals cannot be indifferent, since profit sharing between the TVEs and local governments is an important source of the latter's revenue. The size of TVEs also makes for shrinking span of control by local government of management, thereby further reducing the agency problem. Finally, inasmuch as local governments act as interlocutors before regional and centralized authorities, as well as help to secure financing, labour and raw materials for TVEs, transaction costs are reduced, and, as Douglass North (2005) points out, where transaction costs are zero, the neoclassical assumption of optimal efficiency pertains.

The experience of China, where local governments own most TVEs, shows that reforming countries do not have to privatize industrial assets quickly, in order to achieve industrial efficiency and economic growth, in the same way that the HRS demonstrates that the privatization of farmland is not a sine qua non for improving agricultural performance. Assets can be transferred hierarchically, from one level of government to another, rather than laterally, from government to the private sector. In Africa in the 1980s, a major component of structural adjustment programs (SAPs) was the privatization of the state owned enterprises (SOEs), which in the eyes of donors had been one of the causes of the fiscal crisis of the African state, because their soft budget constraints meant that they could rely on their national treasuries for bailouts, even in the face of inefficiency and persistent financial losses. In retrospect, there may have been at least an interim solution situated somewhere between outright privatization and continued ownership of industrial assets by centralized authority, namely: the devolution of SOEs to local authority, especially those connected to agro-industrial processing, and joint administration of these enterprises between hired agents and local principals. Also, budget constraints can be hardened without privatization.

In China the TVE was successful in breaking the historical dichotomy between agriculture and industry, by fostering the integration of these activities. Agriculture and industrialization are not mutually exclusive. 
This has enormous implication for Africa, which processes little of its raw materials into even the most basic of finished products. But what cannot be overemphasized here was the willingness of China to use institutions that had legitimacy among the Chinese people in the pursuit of economic development, rather to import wholesale others that may well have been resisted, because of their unfamiliarity and external sponsorship. It will be further demonstrated in the discussion below that this ability of the Chinese to jettison existing institutions is not limited to one sector; it runs through all the other policy areas and constitutes the essence of disjointed incrementalism.

There have been efforts in Africa to integrate agriculture and industry. In general, they have not worked for several reasons. Firstly, these initiatives entailed the creation of parastatals imposed by the central state; local officials, much less local farmers, had little stake in their success. In China's TVE the reverse pertains. Secondly, agro-industrial parastatals were often too large and had to confront the problem of unreliable supply. Inputs were sometimes in short supply or low in quality, because of improper monitoring of farm production and poor transportation. Thirdly, they operated under conditions of soft budget constraints. The experience of Cameroon Tannery near Ngaoundéré (Adamawa Province) in the 1980s was emblematic. Hide and skin needed by the firm to make leather would often arrive with blood and other residues of slaughtered animals; they were also mislabelled so that the finished product would be of inferior quality, which damaged the reputation of the firm. But as long as Cameroon Tannery could depend on its parent ministry (MINEPIA) and the central treasury (MINEFI), it had no incentive to engage in quality control of its supplies. China's TVEs, as seen earlier, faced hard budget constraints; they are completely decoupled from Beijing. The uncertainty occasioned by their independence provides a strong incentive to performance.

\section{Finance}

The financial system is the lubricant of any modern economy. When it ceases to grease the wheels, the economy grinds to a halt. A good financial system does two things: mobilize capital (i.e. savings) and direct it unto areas of high return on investment (ROI) and low risk. China's financial system is one of the best in the world at mobilizing resources. On average Chinese citizens save 35 percent of their disposable income, 
most of which goes to bank deposits (checking accounts) and savings accounts. A number of factors help to explain China's high savings rate.

Government-backed postal savings accounts provide a safer place for Chinese citizens to put their money than teapots. The yuan renminbi (RNB) is not (yet) easily convertible, as the Chinese government limits citizen access to foreign currencies. This makes it extraordinarily difficult for small savers to keep accounts in foreign banks, which until 2006 were excluded from the Chinese banking system, where four state-owned banks intermediated 75 percent of all deposits. Until recently, bank deposits were the only option for Chinese savers, as opportunities for investment in the 'irrational exuberance' of stock ownership were foreclosed by the state. Finally, as China has reduced poverty and increased the size of its middle class, Chinese families simply have more disposable income to save.

China uses its financial system to channel capital into preferred areas of economic development, and the People's Bank of China relies on administrative control rather than market forces. Through the central bank the Chinese state maintains overall control of monetary policy and through the state-owned commercial banks it channels capital to specific industries, but regional and local officials can (and do) attract private, even foreign, capital to their area. They do not have to rely on financing from the institutions of the central state. In addition, thanks in large part to money transfers from overseas Chinese, China has a large informal lending market with estimated assets of 100 billion USD (Farrell and Lund 2006). Smaller firms are able to find capital for investment in the informal sector, when they cannot acquire foreign capital through joint ventures or domestic capital from the state-owned banks. Some TVEs also own banks and credit unions. These are further sources of capital for small business.

In sum, the market for capital in China evinces diversity through decentralization, precisely the features of disjointed incrementalism prevailing in other sectors of the economy. But the People's Bank of China, the central bank, continues to exert strong control over monetary policy and financial institutions, again, further evidence of disjointed incrementalism in action. Chinese monetary policy has been one of the reasons behind the success of China in international trade. But China did not officially embrace currency devaluation to stimulate export, the usual elixir of neo-liberals. This may have enabled Chinese officials to resist Western pressure to revalue the yuan in order to reduce China's huge 
trade surplus. Rather, Chinese policy has been to keep the yuan stable while building China's already huge reserve account (over I trillion USD).

The pathologies of Africa's financial system are one of the causes of the continent's underdevelopment. Officially, savings rates throughout Africa are extremely low. As a result, banks lack capital to finance large scale investments. But even moderate scale investments cannot find financing. The environment in much of Africa is perceived as risky, therefore, banks levy high interest rates on loans and place cumbersome requirements on borrowers, which force many small firms to seek financing in the informal sector, forego expansion and (or) raise capital internally (through savings).

Furthermore, bank lending in Africa tends to be of a political, rather than commercial, character: politically connected 'big men' are lent money; 'small boys' are kicked to the sidewalk, or otherwise discouraged from even knocking on the door. Viable business plans are not financed, because banks do not take even reasonable risks or they unfairly discriminate among borrowers. Finally, in parts of Africa (Francophone Africa) central banks do not have autonomy in making monetary policy. In reality, they are local and regional subsidiaries of foreign monetary authorities (e.g. Bank of France). How can development take place under this condition, when its engine (capital) has been effectively removed from the control of Africans? The need for an African 'big think' (nationalism) is no more glaring than in this area.

Fortunately, there are in Africa, as in China, institutions that can play an important role in the financial sector. They are not necessarily stateowned institutions, such as central banks; still, African governments can influence how they work. In Ghana, traditional, pooled savings institutions (essusus) number 5,000 and are estimated to hold 140 million USD in total capital. The amount of periodic contributions to the common pool in an essusu (or tontine in Cameroon) varies. In principle, therefore, even the poorest Ghanaian can be a member of an essusu. Ghanaian banks, on the other hand, require customers to maintain a monthly minimum balance of 150,000 cedis in their account, or the equivalent of one-month salary (Marrot, Barrohi and Ghabi 2007). It should not be too hard for the reader to guess which savings institution ordinary Ghanaians prefer. Insofar as they remain largely in the informal sector, essusus, tontines and other institutions like them constitute a leakage out of the national savings stream, with deleterious consequences on investment. A relatively easy step by government would be to enact policy that brings pooled 
savings institutions from under the shadow of informality. Encouraging essusu and tontine managers to embrace sound methods of bookkeeping and providing ordinary members legal titles to assets would increase credit worthiness and facilitate access to capital from banks and financial institutions.

Remittances are playing an important role in developing countries. In 2005, they were twice the amount of official development aid (ODA) at 188 billion USD (Gupta, Pattillo and Wagh 2007). They are the second largest source of foreign exchange earnings after gold in Ghana, and far surpass foreign aid (all sources combined). In Senegal, remittance inflows from 2000 to 2005 represented, on average, 7 percent of GDP and 22 percent of export earnings (ibid). However, in spite of their increasing importance, remittances in Africa suffer from the same deficiencies as remittances from immigrants elsewhere, namely, they are used mainly for consumption rather than investment and are not taxable. Yet, they could be an important source of capital for many capital-starved countries.

One of the critical sources of capital for China, especially during the early years of economic liberalization (1979-1989), was Hong Kong, then a British colony. Taiwan alternated with Japan as the biggest investor in China during this period as well. Simply put, overseas Chinese were not negligible in the success of China. The push of economic stagnation and population growth may have led to them to take physical leave of the homeland, but the emotional pull of nationalism and familial obligations compelled them to keep their wallets open. In the age of globalization, savings need not come from the citizens who live and work inside the borders of the states that claim them. African states have some distance to travel before they can 'capture' (perhaps a poor choice of word) the savings of their internal citizens for development, much less those living overseas. But the larger point is that there are in Africa sources of capital that are yet to be mobilized for development, some of which go back to the colonial period. The World Bank is expendable. Indeed, World Bank capital constitutes a very small fraction of annual capital flow, respectively 23 billion USD versus 647 billion USD in 2005. Africa may never develop, if it counts on the World Bank as its financier. The Bank played a very minimal role in China's development. 


\section{Industry and Direct Foreign Imvestment (DFI)}

The development of an industrial sector in China was made possible in part by the creation of Special Economic Zones (SEZs), whose history bears further testimony to incremental policy making. The State Council of China, the highest executive body in the PRC, authorized the creation of the first SEZs in 1979 in the provinces of Guangdong and Fujian. The choice was not entirely coincidental. These provinces were located in China's southeast coast, a geo-strategic area rich in labour resources and a cosmopolitan culture, which shared linguistic and economic ties to overseas Chinese business communities in Hong Kong, Taiwan and even Singapore (Wei 1999). These provinces were China's window to the outside world in the late nineteenth century, but the Chinese state could exercise control over the SEZs to a much greater extent than imperial authority could influence the 'Open Door Policy'.

In Guangdong the SEZs were located in Shenzhen, Zhuhai and Shantou and in Fujian Province there was one SEZ in Xiamen. (For those unfamiliar with China, the four zones were located either near Hong Kong, Taiwan or Macao). The SEZs were not the usual free trade zones thrust upon developing countries by donors in the name of liberalization; they were more than semi industrial enclaves where multinational corporations received generous tax breaks in exchange for creating a limited number of jobs with few fringe benefits, and with no visible connection between their activities and the rest of the economy. Instead, the goal of the SEZs was 'to experiment with the development of an outward looking, market oriented economic system, and to serve the country as a "window" and a "base" along these lines ...The rest of the domestic economy could be connected to the outside world through the window, without leaving the door wide open' (ibid).

The SEZs were not created out of thin air. The Chinese government incurred significant start-up costs to bring them about. The SEZs were to be self-standing entities with their own sewer system, electrical power grid, housing stock, health facilities, schools and of course factories and storage facilities. In addition, the Chinese state issued a set of policies and regulations governing the operations of the SEZs that no doubt facilitated their success. China, in a limited way, reformed its property rights and contract laws, making them more transparent and predictable to foreign investors. According to one scholar, 'The regulations concerned such matters as equity ratios of foreign investors, the length of contract periods, employment and wages, land use, corporate and individual in- 
come taxes, business regulation, entry and exit procedures, foreign exchange transactions, technology transfers, patent rights, and visa applications' (ibid). China did not simply designate parts of its territory as SEZs and blindly invite foreign investors to come in. It set conditions aimed at benefiting China as much as international capital.

At least two lessons stand out from China's experience with the SEZs. Firstly, the SEZs were adaptations to existing institutions. All of the first-generation SEZs were located in parts of China that had long been integrated into the world economy. Once again, the role played by overseas Chinese in Hong Kong and Taiwan cannot be underestimated. China did not decline capital from Taiwan because of political differences with the island's leaders. Thus, in the mid-1990s Hong Kong and Taiwan were, respectively, the two biggest investors in China, ahead of the United States (Sun and Tipton 1998). Secondly, China's SEZs demonstrate that comparative advantage is dynamic rather than static; but, more importantly, in the modern world system comparative advantage is manufactured by states rather than bestowed by nature. China had been the world's most populous country for centuries, but its bountiful supply of cheap labour did not suffice to attract foreign capital before 1978. The clincher was a series of policy decisions by the state, from limited reform of property rights to investment in fixed and human capital to decentralization that gave foreign capitalists the confidence that China was worth the risk.

China's experience with SEZs calls attention to the need for states to enact policies that actively promote direct foreign investment while insuring that it benefits the whole economy, not just enclaves thereof. China also demonstrates that it is unwise to inject state capital into industrial ventures indefinitely, lest this creates soft budget constraints. SEZs were supported by the state only in their infancy; they were expected to be self-sustaining soon thereafter. In other words, their budget constraints were hardened as soon as they started production. There have been attempts in Africa to create the institutional equivalents of SEZs and, more generally, attract direct foreign investment. Their failure is instructive and highlights the differences with China.

Firstly, these attempts, such as the former East African Community (EAC), did not bear fruit because of rivalry among African governments (socialist Tanzania versus capitalist Kenya). Secondly, they relied far too extensively on foreign capital for African industrialization. As a result, foreign capital often engaged in a kind of striptease, pitting one 
solicitous African country against another, which no doubt exacerbated the first problem. Thirdly, inadequate infrastructure has impeded direct foreign investment in Africa, as have government inconsistencies in fiscal, monetary and investment policy, which create uncertainty among investors. Fourthly, and perhaps more importantly, industrial and free trade zones in Africa have tended to result in the creation of enclaves with little forward and backward linkage industries and, therefore, no serious connection to the rest of the economy. They have not been vectors of genuine technology transfer. Rather, they have been heavens for capital in search of cheap labour, raw materials and tax exemption.

China's experience with SEZs compels rethinking of the forces that may exist in Africa and the Diaspora that may facilitate capital penetration of the continent. Capital from overseas Africans, including AfricanAmericans, could play a role in the development of the continent. Furthermore, certain groups in Africa known for their entrepreneurial spirit and extensive social networks (réseaux) may be of use in integrating the African continent in the grid of globalization. Because of their 'otherness', these groups have generally been considered suspect by African state elites, if not to say ordinary Africans (e.g. Lebanese and Syrians in West Africa, Indians and Pakistanis in East Africa). In turn, they may not have invested as much in the continent as they could have, which reinforces suspicion. Political uncertainty and popular envy always breed conservativeness in business practices by visible minorities. It may not be entirely coincidental that Uganda's economic performance improved in the wake of a more accommodating stance vis-à-vis entrepreneurs of Asian origin by President Yoweri Museveni.

\section{Chinese Lessons, African Hope}

There is nothing mystical about Chinese economic performance. In fact, many of China's reforms had antecedents elsewhere in Asia and well beyond. The enabling conditions for economic development are fairly well understood by now. They include an ability to produce food, which makes for a healthy population and 'primitive' capital accumulation; a working financial system, to mobilize savings and channel it to productive use, and stable monetary policy; an industrial sector that transforms raw materials into finished products that people want to buy; investment in human and fixed capital; controlled interaction with the outside world; and, above all, a working state that can facilitate the attainment of the aforementioned conditions, craft and enforce property rights that 
are consonant with societal values, provide social services, maintain internal order and protect its border from external predators. This is a way of refuting ahistorical, culture-based and metaphysical explanations of Chinese economic success, and embracing agency in economic development. It is also an affirmation that Africa's challenges are not immutable; they, too, can be overcome by human action. Future generations may regard the continent's alleged neopatrimonialism, social capital deficit, bad geography and other expressions of Afro-pessimism with the same curiosity as the dour prognosis heaped upon Asia by Western thinkers (among them Karl Marx) for its 'despotism'.

The universality of the state as the dominant mode of socio-political organization entails that, for the foreseeable future, it is likely to remain the primary source of human agency in development. The fact is, in the modern age there has not been a single country that was poor and became rich without a state. Political order is a predicate for development and survival. 'Without order, there is no future' (Bates 2007). Therefore, economic development is essentially a state project. Globalization does not exclude the need for states but rather amplifies it. A market system does not vitiate the need for a state. On the contrary, inasmuch as competitive market economy entails a complex property rights system, this makes a working state all the more indispensable, in order to reduce transaction costs, which, in turn, facilitates efficiency. The benefits of the Chinese model, as compared to that of the neo-liberal model, are precisely that the former combines state and market, rather than chooses one over the other.

However, having a state does not guarantee development any more than having a market insures prosperity. The states that have succeeded in achieving development have been precisely those whose leaders have understood the connection between state making, prosperity and their own survival and have been willing to make the requisite decisions to achieve all three within an overarching discursive paradigm of nationalism. This is referred to as 'big think' in this article which shows how it has operated in the Chinese context. At the same time, to acknowledge that economic development has been (is) far too complex and important a matter to be left to the hazards of chance rather than the capable hands of human agency is not to suggest that there is one road to prosperity and only states have the map. The history of development is replete with well-meaning state plans that went awry with disastrous consequences, not least in China (Scott 1998). The centrality of the 
state does not justify turning it into an object of idolatry, for, as the experience of China suggests, there is no magic wand in development, 'no do-it-yourself growth kits that one can simply borrow from others and apply'. (Mkandawire 2005)

Instead, development presents problems of the type that the late professor Martin Landau might have called 'wicked', that is to say, problems that engender concord in regards to ends but discord in regards to means (Landau 1986). In such cases, decision makers, Landau always counselled, should experiment, proceed with caution, respect social institutions that have withstood the test of time, and engage in trial and error. More importantly, they should create mechanisms for error detection and correction, a key element of which is 'redundancy', which localizes mistakes (Landau 1969). This approach to policy is referred to as disjointed incrementalism, in order to underscore its decentralized, experimental, and therefore tentative, character. But policy never takes place in a political vacuum. In the case of China, the political ideology of 'big think' (or nationalism) has largely informed the policy of disjointed incrementalism.

It is doubtful that without the vision provided by Mao Zedong of a strong, united, independent and self-reliant - in short, an erect - China, economic development could have been achieved. It is equally doubtful that without fragmentation of decisions and implementation - in sum, policy experimentation - China could have succeeded. China is simply too complex for the synoptic solutions embedded in previous reform efforts (e.g. Great Leap Forward) to have been successful. In the end, the main lesson provided by China to Africa may be this: make states that captivate the imagination of citizens and gain their support through a nationalist project, but have state leaders who, cognizant of their bounded rationality, are willing to pursue development resolutely but cautiously. What kind of state is likely to capture the imagination of Africans and gain their support?

\section{Toward a Plausible Airican 'Big Think'}

Because of the trauma wrought by the triple experience with the slave trade, colonialism and post-colonialism, and the yearning that all three naturally create for unity, Pan-Africanism is still the most potent, credible, political ideology among the masses in Africa today. It could, and probably must, be Africa's 'big think', if Africa has any realistic chance of being the world economy's next success story. In other words, Pan- 
Africanism should be the organizing principle or ideology of a new African statecraft to replace the partitioning schemes of King Leopold II, Otto von Bismarck and other scramblers. An ideology, of course, 'is an economizing device by which individuals come to terms with their environment and are provided with a 'world view' so that the decision making process is simplified' (North 1981).

Thus, ideologies are like theories: they rationalize and explain a given situation, while providing possible alternatives that are adduced to be better than the status quo. An ideology therefore is always at least a latent call for action. What the African state, as it is currently constituted, lacks then is a credible ideology capable of explaining Africa's political balkanization, that is, its 50-odd states in light of potential mass support for considerably fewer, its underdevelopment in the midst of the bountiful natural resources bestowed by the gods (yes, the gods), its marginalization in the concert of nation-states in spite of a Diaspora that is truly global in character and relatively prosperous. Worse still, the modern African state, too Lilliputian in many places to be recognizable even on an African map, is not capable of providing strategies, or devising plans, that would liberate the continent's arrested development. Enter Pan-Africanism, the case for which is basically three-fold.

Firstly, "Africa" is probably the most emotionally evoked name of any continent. Its people sing about it, paint it, sculpt it more than any other continent. Its artists produce hundred of icons of this much "beloved continent". Even national anthems often evoke Africa much more than individual country names' (Mkandawire 2004). In other words, 'Africa' has a greater hold on the collective imagination than any other concept. It would be far easier to rally Africans around 'Africa' than any other social project, in the same way that Mao Zedong rallied the Chinese around 'China First.'

Secondly, de facto Pan-Africanism exists throughout the continent. It is to be found in the existence of formal and informal institutions - e.g. chieftaincies, secret societies, trade networks, land property rights, language families, religions, etc. - that cut through large swaths of the continent. In this connection, ordinary Africans are well ahead of their rulers, whose indifference, if not to say hostility, to the Pan-African project has been deleterious to its progress. The main obstacle to development in Africa may well be how to align the interests of territorially bound rulers with the transcendent institutions of citizens, who are more likely to 
support development efforts if they are consonant with existing practices and values.

Thirdly, Pan-Africanism is firmly in line with trends in the world geopolitical economy, whose logic calls for large and transnational entities. These are legion: multinational corporations (GM and Wal-Mart), free trade blocs (NAFTA), confederations (EU), international financial institutions (World Bank, IMF), regulatory organizations (WTO), terrorist outfits (al-Qaeda), criminal syndicates (the Russian Mafia in Moscow, London and Brighton Beach, New York City), etc. In the age of globalization, bigger may not always be better (as the experience of DaimlerChrysler demonstrates), however, it often provides greater insurance for survival in a turbulent environment.

The concrete benefits of Pan-Africanism have long been identified but they are worth summarizing. Pan-Africanism would allow Africa to take advantage of the economies of scale that accrue with larger markets (Green and Seidman 1967). It would allow Africa to better leverage its natural resources, some of which can only be found on the continent, in the same way that China has leveraged its population to attract capital. It would facilitate the connection of landlocked territories to the world economy and raise them up from poverty. Concomitantly, it would allow for easier sharing of resources between rich and poor communities, for the same reason that Germans have been willing, in effect, to transfer resources to Poles and Irishmen: 'Europe'. It would give the continent greater clout in the world economic order and on the tribune of international opinion (the UN), as it would be able to speak with one voice rather than many (Mandaza 2002). It would reduce interstate wars, in the same way that the EU has kept the peace among Europe's historical warring factions. It would reduce intra and interstate conflicts, by delocalizing identity (How many lives have been lost in Ivory Coast because of Ivoirité, which may have begun as little more than a cynical ploy by some Ivorian politicians to rally their electoral base but turned out to have deadly consequences?). It would increase democracy, as local scoundrels would no longer be able to take refuge in raison d'état and sovereignty. In sum, Pan-Africanism would facilitate development, by removing what may well be the main barrier to prosperity in the African context: the tension between the territorially bound, mostly debile, predatory African state and the transcendent and vibrant institutions of African civil society, which are also consonant with globalization. The 
criticisms of Pan-Africanism have been heard before. They are refuted one-by-one here.

Pan-Africanism is not a pipe dream that is simply too complex to be implemented. It is seldom recalled today that the European Union, one of the most successful 'big think' products of our time, began modestly as a customs union of coal and steel among 6 countries of northern Europe, which more than 50 years later has its own currency, 27 member states, a parliament and perhaps soon a constitution. Nor is it remembered that before 1949, China was a virtual doormat of imperialist powers. All this began to change with one simple but solemn declaration in September of that year and China has never looked back (i.e. 'The Chinese people have stood up'). But Pan Africanism does not gainsay experimental policy making (disjointed incrementalism), beginning perhaps with economic institutions operating, at first, at regional levels. For example, South Africa's Rand could be the medium of exchange for the southern Africa region. China's SEZs, HRS and TVEs began as modest experiments in a larger framework of modernization.

Pan-Africanism does not immediately necessitate continental government, although in the long run this may well be the outcome. But even then such a government would almost certainly be the result of painstaking negotiations among local stakeholders. Therefore, it would likely be a federation or confederation, leaving significant powers to non-central authorities. Because many African states have undergone a democratic transition since 1990, such a (con)federation would also likely consist of democratic states. Pan-Africanism is not African Big Brother coming to consume its junior siblings. But there would have to be certain markers or, as the British like to say: red lines. These are fundamental principles upon which action aimed at achieving Pan-Africanism would be built, rather than principles Pan-Africanism would seek to avoid in the interest of amity and political correctness. One of these markers would be the integration of geo-political space, which would of course calls into question the secular sanctity of the borders drawn at the Berlin Conference, the proverbial elephant in the room at Casa Blanca and in Addis Ababa in 1961. Another is social inclusiveness.

Pan-Africanism cannot succeed unless it directly and concretely benefits ordinary Africans, in the same way that President Hu Jintao's recently enshrined concept of 'scientific development' is aimed at extending the benefits of economic growth to even more Chinese citizens while cleaning up the environment. Thus, Pan-Africanism should not be con- 
ceived as some grand political project, whose utility to the African masses is largely emotive or symbolic. Fundamentally, then, Pan-Africanism would be a social project. It would put socialism 'back in' on the African agenda, in counter-distinction to donor-imposed efforts to integrate Africa in the global capitalist order as a primary commodity producer - still.

Pan-Africanism is the highest expression of African nationalism and clearly incompatible with the arbitrary borders that zigzag the African landscape, but it is not black racism. This would presuppose the strict equation of Africa with the black 'race', and no such infantile presumption is made here. As quite possibly the birthplace of humankind and the literal centre of planet Earth, Africa has always been a meeting point for all groups, the preponderance of the black epidermis in much of the continent having more to do with geography and nature's adaptation to disease threats than any propensity of Africans toward exclusivity. Racist, in fact, is the belief that Africans cannot undertake collective action to solve their own problems, and, therefore, will always need outsiders.

Pan-Africanism does not negate developmental states, on the contrary, it strengthens them through consolidation. One reason why developmental states in Africa would have a difficult time pursuing development on their own would be the expected pressure they would experience to open up their economies, in particular by the World Trade Organization and the United States. The Asian developmental states (Japan, South Korea) were either spared the unpleasantness of neo-liberal orthodoxy - because of the special circumstances of the Cold War - or could resist it by their sheer weight in the world geo-political system (China).

No preferential treatment would likely be granted individual African developmental states, as the imposition of structural adjustment programs in the 1980s made clear. Simply put: individual African developmental states would have to sink or swim without life vests; Pan-Africanism, by amalgamating states into large blocs (and, why not, eventually into one), would enable them to better negotiate the treacherous currents. Furthermore, many countries in Africa have similar economic profiles as primary commodity producers. Untrammelled competition for capital could have effects akin to the behaviour of crabs in a basket, whereby those at the bottom trample on their neighbours to reach the top, only to be thrown overboard. As seen earlier, this was one of the problems with the old EAC. Because of division, African countries are reduced to being the political equivalents of stage performers in a burlesque show in a second-hand theatre where the rewards are mini- 
mal in the end. Pan-Africanism would insure rationality and coordination in African developmental efforts. In sum, there may be no African future without the Pan-African developmental state.

Pan-Africanism has not really been tried in Africa in the post-colonial period, therefore, it cannot be said to have failed. Pan-African projects, from continent-wide efforts such as the OAU to regional initiatives such as, once again, the EAC, never received the strong and consistent support from African rulers that would have been necessary for their success. The leaders of these organizations never transcended parochial interests for the sake of collective wellbeing. Their adhesion to PanAfricanism did not extend beyond the pageantry of the annual meetings, that is, if they showed up at all. Finally, post-colonial, so-called Pan-African efforts were all predicated on the acceptance of the imposed artificialities of the Berlin Conference, the very anti-theses of African development and Pan-Africanism itself.

Of course, there is no absolute guarantee that things would be better this time around, but perhaps Pan-Africanism could avoid the ignominy of its putative antecedent, given the ongoing democratization of the continent, which should facilitate the peaceful retirement of reactionaries, and the ubiquity of similar efforts elsewhere, which may have awaken Africans out of their stupor. In this connection, the decision to create a (Pan)-African parliament, à la European parliament, may be more than symbolic. For the first time in post-colonial Africa, the African masses would have an institution they can directly affect across borders. For Pan-Africanists, the task is clear under this dispensation: elect to the (Pan)-African parliament, whenever it becomes operational, committed Pan-Africanists, who would then use the institution as a launching pad to deepen Pan-Africanism in their 'home' country and continent-wide.

Obviously, Pan-Africanism would not be easy. There would be enormous problems integrating countries that are differentially endowed in natural and human resources, do not share the same geography, culture and so on. Yet, in spite of its unquestionable diversity, there is probably more that unites Africa than divides it. There would also be external resistance by imperialist powers that continue to regard large swaths of the continent as their exclusive chasse gardée (prey). Overall, the difficulties that Pan-Africanism can be expected to encounter by no means make its realization impossible, only marginally more difficult if there is strong leadership commitment. Besides, we are not suggesting that Pan- 
Africanism can be built in the course of one generation; it would be une marche à longue haleine, a marathon that could take decades to complete.

In some ways, Africa is today where China was before 1949: weak and wracked by division and 'warlordism'. Just as it took a social revolution to unite and bring order to China under the authority of one state, the same may well be necessary in some African countries whose disintegration is probably past the point of ordinary reform (e.g. Nigeria and Congo). No matter the human costs of this possible denouement, those connected to continued misery and marginalization are probably much higher. But one last time, as the example of China shows, the price of development is state activism, big and disjointed, not immobility, supplication and unshaken belief in the power of the market.

\section{Notes}

1. A developmental state may be defined as a state that uses its authority to intervene significantly in the economy, in order to promote substantive goals, such as export competitiveness, industrialization and food self-sufficiency. More broadly, a developmental state is actively engaged not only in the traditional areas of statecraft, i.e. security and stability, but also in prosperity.

2. An administrative system that grants local officials substantial autonomy in implementing policy, by default, also grants them substantial ability in making policy. At the same time, inasmuch as centralized authority maintains penultimate power over local officials, as reflected in the carrying out of capital punishment against corrupt local apparachiks in China, the central state remains the formal/legal epicenter of policy making, even though, in practice, the latter may be surreptitiously appropriated by subalterns. This 'problem' is not unique to China. The general currently in charge of U.S. troops in Iraq, David Patraeus, is effectively making war policy as much as he is implementing it.

3. China may have been so blinded by illusion of its grandeur that it may have ultimately handed its occupiers the key to its own defeat. By failing to modernize China, based in part on the belief that China was already modern, the late Ming dynasty was in no position to resist foreign encroachment. The inability was further aggravated by nasty palace intrigues, which kept Chinese rulers isolated from their own retainers.

\section{Bibliography}

Avery, N., 2005, Bloomberg News, 9 August.

Bates, R. in G. Munck and R. Synder (eds.), 2007, Passion, Craft and Method in Comparative Politics, Baltimore, MD: The Johns Hopkins University Press.

Brown, L., 2004, 'China’s Shrinking Grain Harvest', The Globalist, Friday, March 12. Chan, S., 1990, East Asian Dynamism, Boulder, CO: Westview Press. 
Chen, F., L. Wang and J. Davis, 1989, 'Land Reform in Rural China Since the Mid1980s, Parts I and II', www.fao.org/sd/Ltdirect/Ltan0032.html.

Diamond, J., 1997, Guns, Germs and Steel; The Fates of Human Societies, New York: W.W. Norton.

Etzioni, A., 1967, 'Mixed-Scanning: A 'Third' Approach to Decision-Making', Public Administration Review, December, pp. 385-392.

Farrell D. and S. Lund, 2006, 'Putting China's Capital to Work', www.feer.com/ articles 1/2006/0605/free/p005.html.

French, H., 2006, 'As China Ages a Shortage of Cheap Labor Looms', New York Times, June 29, 2005.

Fu, X. and V.N. Balasubramanyam, 2002, 'Township and Village Enterprises in China' Lancaster University Management School, Working Paper, http:// www.lums.co.uk/publications.

Gale, F. and R. Collender, 2006, 'New Directions in China's Agricultural Lending', Electronic Outlook Report from the Economic Research Service, www.usda.gov, January.

Gordon, R. and I. Waldner, 1979, 'Thinking Big, Thinking Small and Not Thinking At All', Public Policy, Vol. 27, No. 1, Winter. pp. 1-24.

Green, R. and A. Seidman, 1967, The Economics of Pan-Africanism - Unity or Poverty, Baltimore: Penguin Books.

Gros, J-G., 2003, 'Trouble in Paradise: Crime and Collapsed States in the Age of Globalization', The British Journal of Criminology, Vol. 43, No. 1, Winter. 63-80.

Gupta, S. C. Pattillo and S. Wagh, 2007, 'Making Remittances Work for Africa', Finance and Development, Vol. 44, No. 2, June.

Haishun S. and F.B. Tipton, 1998, 'A Comparative Analysis of the Characteristics of Direct Foreign Investment in China, 1979-1995', The Journal of Developing Areas, Winter, pp. 159-186.

Hsu, I., 2000, Rise of Modern China, New York, NY: Oxford University Press.

International Finance Corporation, Doing Business: Economy Characteristics, http:// www.doingbusiness.org/ExploreEconomies/Economy Characteristics.aspx.

Jeune Afrique l'Intelligent, 2004, 'Chic, les Chinois reviennent', 31 January.

Landau, M., 1969, 'Redundancy, Rationality, and the Problem of Duplication and Overlap', Public Administration Review, July/August, pp. 346-358.

Landau, M., 1986, 'On Decision Strategies and Management Structures: With Special References to Experimentation', ISARD-Ford Workshop on The Contribution of Management Science to Irrigation Systems, Colorado State University, 15-18 April.

Lindblom, C., 1979, 'Still Muddling, Not Yet Through', Public Administration Review, 39, pp. 517-525.

Makandawire, T., 2004, 'Rethinking Pan-Africanism, $1^{\text {st }}$ Conference of Intellectuals from Africa and the Diaspora', African Union, Dakar, Senegal, 7-9 October.

Makandawire, T., 2005, 'Toward a Development, Democratic and Social Inclusive Africa Once Again', CODESRIA Bulletin, Nos. 3 and 4, pp. 47-49.

Mandaza, I. (ed.), 2002, Pan-Africanism and Integration in Africa, Zimbabwe: SAPES. 
Marrot, J-B., A. Barrohi and S. Ghabi. 2007, 'Ghana: les collecteurs soussous bancarisés', Jeune-Afrique, 25 February.

Melka, J., 2006, 'La Chine usurpe-t-elle sa place de nouvelle puissance commerciale?' Le Monde Economie, 23 May.

Nkrumah, K., 1998, Africa Must Unite, UK: PANAF.

North, D., 1981, Structure and Change in Economic History, New York and London: W.W. Norton and Company.

North, D., 2005, Institutions, Institutional Change and Economic Performance, Cambridge, UK: Cambridge University Press.

Popper, K., 1961, The Logic of Scientific Discovery, New York, NY: Scientific Editions.

Popper, K. 2002, The Poverty of Historicism, New York: Routledge Classics.

Scott, J.C., 1998, Seeing Like a State, New Haven, CT: Yale University Press.

Taylor, I., 2005, 'Can Africa Produce Developmental States', CODESRIA Bulletin, Nos. 3 and 4, pp. 51-52.

Wei, G., 1999, Special Economic Zones and the Economic Transition in China, Singapore University: World Scientific Publishing Co.

World Bank, 1997, China 2020: Development Challenges in the New Century, Washington, D.C.: The World Bank.

Yardley, J. and J. Kahn, 2005, 'China's Great Divide: Rural Poor and Urban Rich', New York Times, 12/18-12/23. 
